SHORT COMMUNICATIONS

\title{
Multisubunit complex eEF1H in human glial tumors: from mRNA to protein
}

\author{
M. V. Veremieva, T. A. Malysheva', Y. P. Zozulya' ${ }^{1}$, V. D. Rozumenko' ${ }^{1}$ L. L. Sidorik, \\ V. M. Kavsan, B. S. Negrutskii, A. V. El'skaya
}

Institute of molecular biology and genetics NAS of Ukraine

150, Zabolotnogo Str, Kyiv Ukraine, 03680

${ }^{1}$ A. P. Romodanov institute of neurosurgery

32, Manuilskoho Str, Kyiv, Ukraine 04050

vermarina@list.ru

\begin{abstract}
Aim. To investigate protein level of all subunits of the eukaryotic elongation translation factor eEF1H

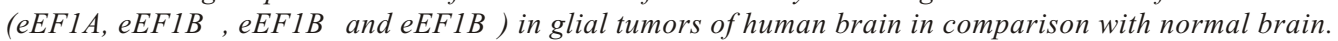
Methods. The eEF1H components content has been investigated in human glioblastoma clinical samples by

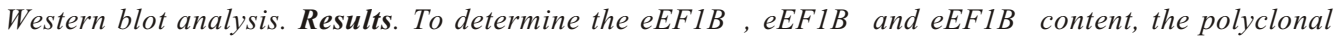
antibodies against all eEF1H subunits were obtained. The tendency of the eEF1B protein level to increase in glioblastomas was observed. There were no significant differences in the eEF1A, eEF1B $\alpha$ and eEF1BB protein contents. Conclusions. In the previous report we analysed the expression of all eEF1H subunits in human glial brain tumor on the mRNA level. This study showed that eEF1B $\gamma$ was overexpressed while no significant changes in other eEF1H subunits were observed. It suggests a possible function of eEFB $\gamma$ which is cancer-related and is not connected with the functioning of eEF1H complex in translation.
\end{abstract}

Keywords: translation elongation factor eEF1H, human glial brain tumors.

Introduction. Elongation factor eEF1H is a multiprotein complex which comprises four functionally different subunits: eEF1A is responsible for delivery of correct aminoacyl-tRNA to the A site of $80 \mathrm{~S}$ ribosome and supposedly facilitates the transport of deacylated tRNA back to aminoacyl-tRNA synthetase for recharging. Structurally different

(C) Institute of Molecular Biology and Genetics NAS of Ukraine, 2010
eEF1B $\alpha$ and eEF1B $\beta$ apparently perform the same function to catalyze exchange of GDP for GTP in the eEF1A molecule, and the eEF1B $\gamma$ subunit is believed to serve as a "glue" to keep all subunits of the eEF1B complex together [1,2].

Recent research has shown overexpression of the mRNA coding for the eEF1H individual subunits in different types of cancer [3-6]. Despite this, there is 
absolutely no information on how the amount of different eEF1H subunits in tissue depends on carcinogenesis. It is believed that the elongation factors are essential for the tumor functioning since the inhibition of polypeptide elongation reduced the tumor chemosensitivity [7].

Previously we demonstrated the changes in the level of mRNA coding for eEF1H subunits in human glial tumors [8]. Glial tumors represent heterogeneous widespread (40\%) intracranial group. Glioblastoma is the most aggressive tumor of human central nervous system with infiltrating ability.

Since the alteration of mRNA amount in tissues does not always correlate with a corresponding protein level we have analyzed whether the amount of eEF1H subunits changed in human glial tumors.

Materials and methods. Tissue samples. Glioblastoma samples (astrocytoma IV grade by WHO classification) were obtained from A.P. Romodanov Institute of Neurosurgery of Academy of Medical Sciences of Ukraine, Kyiv. The surgical samples of histologically normal brain tissue adjacent to a tumor were used as a conditionally normal tissue.

Isolation and purification of anti-eEF1A, -eEF1B $\alpha,-e E F 1 B \beta,-e E F 1 B \gamma$ antibodies. Rabbits were immunized with purified recombinant eEF1B $\gamma(0.15$ $\mathrm{mg}$ in 50\% FCA (Sigma, USA) into six points intradermally on the back. The second injection was performed with the same amount of antigen in FCA 8 weeks later. After 2 months rabbits were boosted with $0.1 \mathrm{mg}$ of antigen in $50 \%$ FIA (Sigma, USA).

Mice were immunized by intraperitoneal injection with $0.02 \mathrm{mg}$ eEF1B $\alpha$ or eEF1B $\beta$ in $50 \%$ FCA. Animals got the same doze of antigen in 50\% FIA four weeks later. The last immunization was performed in 25 days. Rabbits or mice serum was removed in 8 days after the last immunization. The titer of antibody specificity in immunized animal serum was determined by ELISA assay.

Isolation of total immunoglobulin fraction was performed by ammonium sulfate precipitation with subsequent purification on DEAE-cellulose (Serva, Germany) and Protein-G Sepharose (Sigma, USA) according to the manufacturer's protocol.

The antibody specificity was checked by Western blot analysis against recombinant protein and human tissue extract of surgical samples using manufacturer's ECL-system protocol (Pierce, USA).

Western blot analysis. Frozen tissue samples were homogenized in liquid nitrogen and lysis buffer (10 $\mathrm{mM} \mathrm{K}_{2} \mathrm{HPO}_{4} \mathrm{pH} 7.4,100 \mathrm{mM} \mathrm{NaCl}, 1 \% \mathrm{NP}-40,1 \mathrm{mM}$ DTT, $0.1 \mathrm{mM}$ PMSF), incubated in ice bath during 30 min and centrifuged $13000 \mathrm{~g}$ during $20 \mathrm{~min}$ at $4{ }^{\circ} \mathrm{C}$.

Protein concentration was assayed by Bradford's method [11]. The equal amount of each protein extract was resolved by $12 \%$ SDS-PAGE and transferred onto nitrocellulose membrane. The membrane was blocked in phosphate buffered saline (PBS: $1.47 \mathrm{mM} \mathrm{K}_{2} \mathrm{HPO}_{4}$, $4.29 \mathrm{mM} \mathrm{Na}_{2} \mathrm{HPO}_{4}, 137 \mathrm{mM} \mathrm{NaCl}, 2.68 \mathrm{mM} \mathrm{KCl}, \mathrm{pH}$ 7.3) containing $0.1 \%$ Tween-20 (PBS-T) and 5\% powered milk for $1 \mathrm{~h}$, and incubated with primary antibody.

Mouse monoclonal anti-eEF1A (Upstate, USA), polyclonal anti-eEF1B $\alpha$ and anti-eEF1B $\beta$, and rabbit polyclonal anti-eEF1B $\gamma$ were used to estimate a level of corresponding proteins in tissue extracts. After each ECL treatment, the membranes were stripped with PBS-T and re-probed with anti- $\beta$-actin antibodies (Santa Cruz, USA). Endogenous $\beta$-actin was used as a loading control. The densitometry analysis of signals was performed by the Scion Image program. Target protein expression was evaluated using the relative intensity ratio of target protein/loading control.

Results and discussion. Reactivity of polyclonal antibodies against subunits of eEF1B complex $(\mathrm{eEF} 1 \mathrm{~B} \alpha$, eEF1B $\beta$, eEF1B $\gamma)$ with corresponding purified recombinant and endogenous proteins as well as the absence of recognition of nonspecific proteins in human tissue extracts were demonstrated using immunoblot technique (Fig. 1).

Western blot analysis of eEF1A amount in glioblastoma as compared with normal samples did not show significant changes (Fig. 2). Earlier we have not observe differences in the eEF1A mRNA expression in tumor and normal tissues [8]. The same situation has been found for eEF1B $\alpha$ while the eEF1B $\beta$ mRNA level in glioblastoma is decreased. Though the total eEF1B $\beta$ mRNA amount in the tumor as well as in normal tissues is very low, a content of corresponding protein in investigated samples is readily detectable by Western blot analysis. The eEF1B $\beta$ amount was found to be equal in tumor and normal tissues (Fig. 2). 


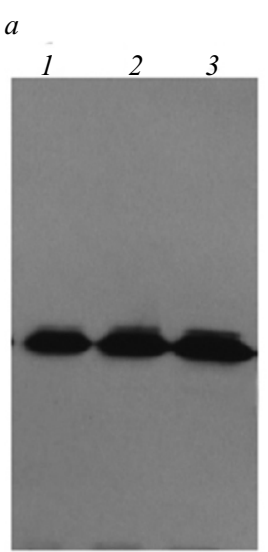

$e E F 1 B \alpha$

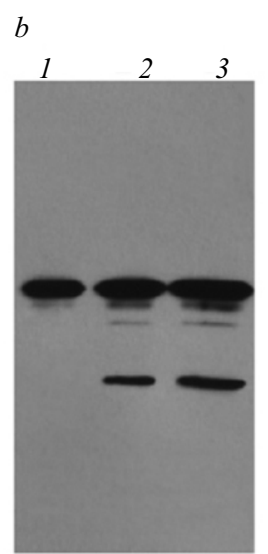

eEF1 B $\beta$

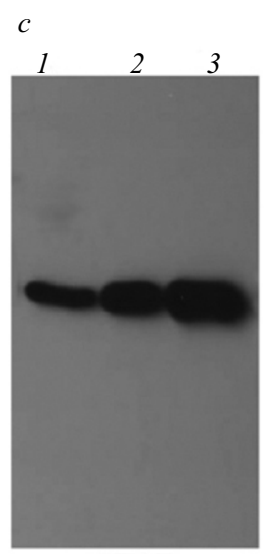

$e E F 1 B \gamma$
Fig. 1. Western blot analysis of polyclonal antibodies against eEF1Ba $\alpha(a)$, eEF1 $\beta(b)$ and eEF1B $\gamma(c)$.

(a) 1. eEF1B $\alpha, 0.1 \mu \mathrm{g}$. 2. Human cardioesophageal tissue extract (40 $\mu \mathrm{g}$ of protein). 3. Human lung tissue extract ( $40 \mu \mathrm{g}$ of protein). (b) 1. eEF1B $\beta, 0.1 \mu \mathrm{g}$. 2. Human cardioesophageal tissue extract (40 $\mu \mathrm{g}$ of protein). 3. Human lung tissue extract ( $40 \mu \mathrm{g}$ of protein).

(c) 1. eEF1B $\gamma, 0.5 \mu \mathrm{g}$. 2. Human cardioesophageal tissue extract (40 $\mu \mathrm{g}$ of protein). 3. Human lung tissue extract ( $40 \mu \mathrm{g}$ of protein).

The tendency of elevation of the eEF1B $\gamma$ level in human glioblastoma (Fig. 2) was noticed. The interesting results concerning the eEF1B $\gamma$ mRNA content have been found recently by us in human brain tumor [8]. Based on the stage disease analysis we have detected the increased eEF1B $\gamma$ mRNA level in astrocytomas WHO grade II - III. However, the decreased eEF1B $\gamma$ mRNA amount has been found in glioblastomas (astrocytoma WHO grade IV) as compared to normal tissue [8]. Thus, the current study does not demonstrate any correlation between changes in the eEF1B $\gamma$ mRNA and protein in glioblastomas which suggests a possibility of post-translation regulation of the eEF1B $\gamma$ level in this type of tumor.

An increased amount of mRNA coding for eEF1B $\gamma$ was found in breast, gastric, colorectal and pancreatic tumors by other authors [12-15]. In our study the first evidence of cancer-related increasing of eEF1B $\gamma$ in glioblastoma has been obtained. The lack of coordinated changes in a level of other components of the complex may indicate the appearance of free eEF1B $\gamma$, which is not involved in the multisubunit complex in cancer cells. Summarizing our and literature data we hypothesize that $\mathrm{eEF} 1 \mathrm{~B} \gamma$ may possess other than translational function during carcinogenesis. For instance, eEF1B $\gamma$ was reported to perform a specific function separately from the complex in the oxidative stress response [16].

This report is the first attempt to study cancer-related changes in the amount of all components of the elongation translation factor eEF1H on the protein level. Unfortunately, restricted availability of the biological material did not allow us to investigate sufficient quantity of normal human brain samples for the classical statistical analysis. The changes in subunits level and tendency of increasing eEF1B $\gamma$ amount in cancer will be investigated in further experiments with tumors of different localization.

Conclusions. The comparison of amount of different subunits of multiprotein elongation translation complex in human glioblastomas and normal brain tissue was performed using Western blot analysis.

The antibodies against eEF1B $\alpha$, eEF1B $\beta$ and eEF1B $\gamma$ were obtained. No cancer-related changes in the amount of eEF1A, eEF1B $\alpha$ and eEF1B $\beta$ were found except the tendency of increasing eEF1B $\gamma$ amount in tumors.

The up-regulation of only one eEF1H subunit indicates that $\mathrm{eEF} 1 \mathrm{~B} \gamma$ might perform a separate cancer-related role besides its eEF1H-related translation function.

The investigations were partially supported by SFFR of Ukraine $\Phi 28 / 276-2009$ and cooperation program between NAS of Ukraine and CNRS. We are indebted to prof. V.V. Filonenko for the help in the production of antibodies.

М. В. Верем'єва, Т. А. Малишева, Ю. П. Зозуля,

В. Д. Розуменко, Л. Л. Сидорик, В. М. Кавсан,

Б. С. Негруиький, А. В. Сльська

Мультисубодиничний комплекс еEF1Н у гліальних пухлинах головного мозку людини: від мРНК до білка

Резюме

Мета. Проаналізувати вміст усіх субодиниць фактора елон-

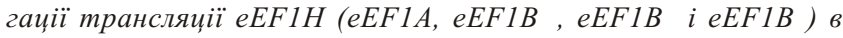
гліальних пухлинах головного мозку людини порівняно з умовною нормою. Методи. Компоненти комплексу еЕF1Н досліджували у клінічних зразках гліальних пухлин людини Вестерн-блот-аналізом. Результати. Для визначення вмісту

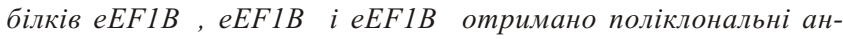




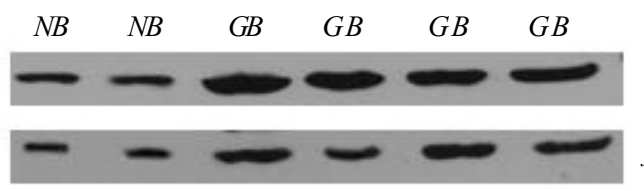

eEFI A

Bactin
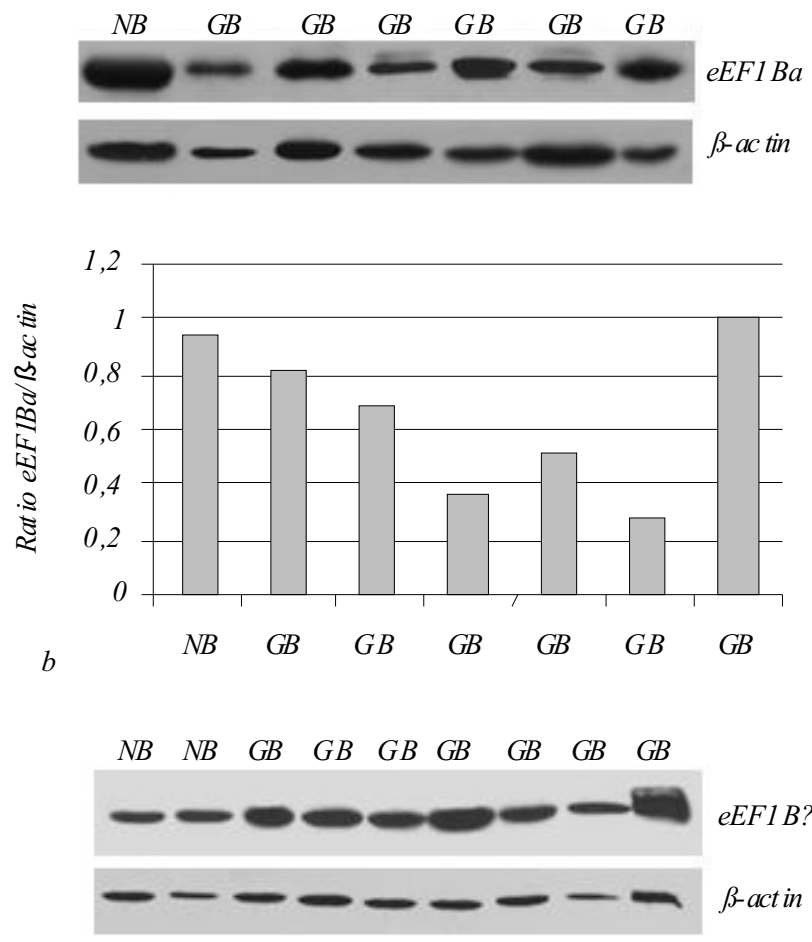
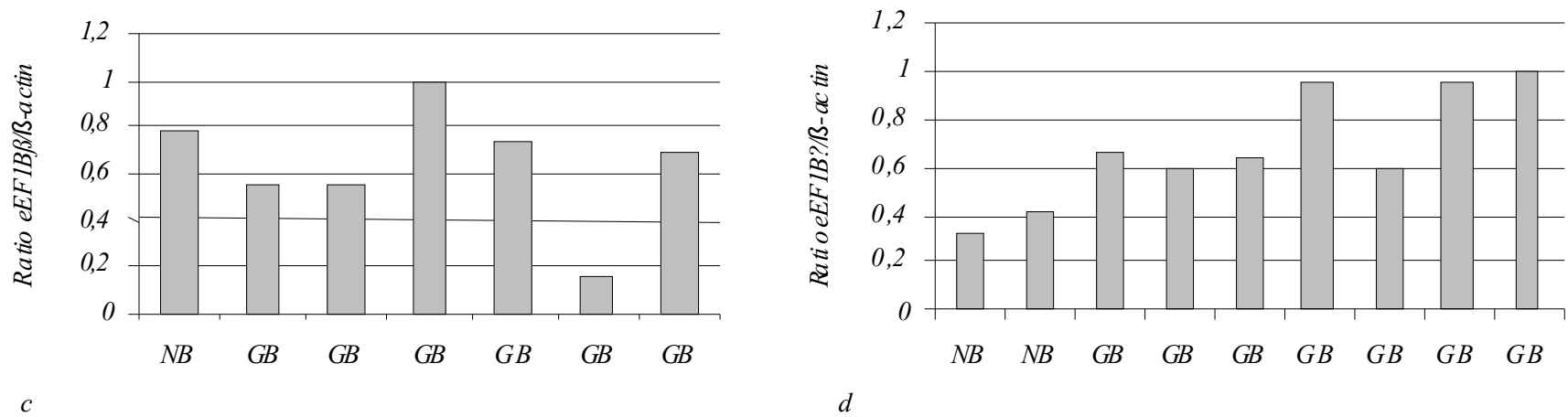

Fig. 2. Comparative analysis of the level of eEF1H subunits ( $a-\mathrm{eEF} 1 \mathrm{~A}, b-\mathrm{eEF} 1 \mathrm{~B} \alpha, c-\mathrm{eEF} 1 \mathrm{~B} \beta, d-\mathrm{eEF} 1 \mathrm{~B} \gamma)$ in human glioblastomas. The densitometry analysis of signals was performed by the Scion Image program. The target protein expression was evaluated using the relative intensity ratio of target protein $\beta$-actin; $N B$ - sample of normal human brain, $G B$ - sample of human glioblastoma.

титіла до ичих субодиниць. Спостерігали тендениію до підвищення рівня білка еЕF1Вү в гліобластомах. Відмінності в рівні

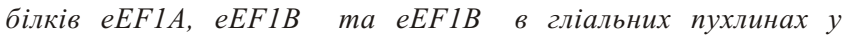
порівнянні з умовною нормою виявилися несуттєвими. Висновки. Ця робота є продовженням попередніх досліджень, де вивчали рівень мРНК, які кодують субодиниці комплексу еЕF1Н у пухлинах головного мозку людини. Виявлене зростання кониентрації білка еЕF1Вү в гліобластомах, щуо від- бувалося на фоні практичної відсутності розбіжностей в експресії інших субодиниць комплексу, може свідчити про виконання субодиницеюю еЕF1Вү певної пухлинозалежної ролі, окремої від трансляційної функиії комплексу еЕF $1 \mathrm{H}$.

Ключові слова: фактор елонгації трансляиії еЕF1Н, гліальні пухлини головного мозку людини.
М. В. Веремьева, Т. А. Мальшева, Ю. П. Зозуля, В. Д. Розуменко, Л. Л. Сидорик, В. М. Кавсан, Б. С. Негруикий, А. В. Ельская

Мультисубъединичный комплекс еEF1Н в глиальных опухолях головного мозга человека: от мРНК до белка

Резюме

Цель. Проанализировать содержание всех субъединии факто-

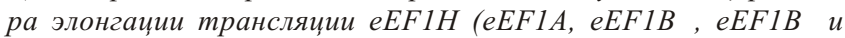

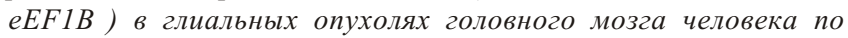
сравнению с условной нормой. Методы. Компоненты комплекса еЕF1Н исследовали в клинических образцах глиальных опухо- 
лей человека Вестерн-блот-анализом. Результаты. Для опре-

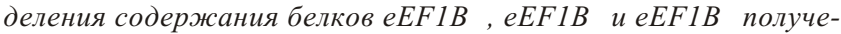
ны поликлональные антитела против этих субъединиц. Наблюдалась тенденция к повышению уровня белка еЕF $1 B \gamma$ в глиобластомах. Отличия в уровнях белков еЕF 1A, еЕF1B и и еЕF $1 B$ $\beta$ оказались несущественными. Выводы. Эта работа продолжает предыдущие исследования по изучению уровня мРНК, кодируюших субъединицы комплекса еEF1Н в опухолях головного мозга человека. Выявленное увеличение кониентрачии белка еЕF1Bү в глиобластомах, происходящее на фоне практически отсутствующих изменений в уровнях экспрессии других субъединии комплекса, может указывать на выполнение субъединиией еЕFIBү определенной опухоль-зависимой роли, отдельной от трансляционного комплекса еЕF1H.

Ключевые слова: фактор элонгации трансляции еЕF1Н, глиальные опухоли головного мозга человека.

\section{REFERENCES}

1. Negrutskii B. S., El'skaya A. V. Eukaryotic translation elongation factor 1a: structure, expression, functions, and possible role in aminoacyl-tRNA channeling // Prog. Nucl. Acid Res. Mol. Biol.-1998.-60.-P. 47-78.

2. IUMBMB. Prokaryotic and eukaryotic translation factors. Ad Hoc Nomenclature Subcommittee Report // Biochimie.1996.-78, N 11-12.-P. 1119-1122.

3. Joseph P., O'Kernick C., Othumpangat S., Lei Y., Yuan B., Ong T. Expression profile of eukaryotic translation factors in human cancer tissues and cell lines // Mol. Carcinogen.2004.-40, N 3.-P. 171-179.

4. Ogawa K., Utsunomiya T., Mimori K., Tanaka Y., Inoue H., Murayama S., Mori M. Clinical significance of elongation factor-1 delta mRNA expression in oesophageal carcinoma // Br. J. Cancer.-2004.-91, N 2.-P. 282-286.

5. Ender B., Lynch P., Kim Y. H., Inamdar N. Y., Cleary K. R., Frazier M. L. Overexpression of an elongation factor-1 gamma-hybridizing RNA in colorectal adenomas // Mol. Carcinogen.-1993.-7, N 1.-P. 18-20.

6. De Bortoli M., Castellino R. C., Lu X. Y., Deyo J., Sturla L. M., Adesina A. M., Perlaky L., Pomeroy S. L., Lau C. C., Man T. K., Rao P. H., Kim J. Y. Medulloblastoma outcome is adversely associated with overexpression of EEF1D, RPL30, and RPS20 on the long arm of chromosome $8 / / \mathrm{BMC}$ Cancer.-2006.-6.-P. 223.

7. Robert F., Carrier M., Rawe S., Chen S., Lowe S., Pelletier J. Altering chemosensitivity by modulating translation elongation // PloS One.-2009.-4, N 5.-e5428.

8. Veremieva M., Shostak K., Malysheva T., Zozulya Y., Rozumenko V., Kavsan V., Negrutskii B. Expression of different subunits of eukaryotic translation elongation factor eEF1 in human glial brain tumors // Biopolym. cell.-2008.-24, N 4.P. 310-317.

9. Kleihues P., Cavenee $W$. K. World Health Organization classification of tumors of the nervous system.-Lyon: IARC/WHO, 2000.

10. Maier T., Guell M., Serrano L. Correlation of mRNA and protein in complex biological samples // FEBS Lett.-2009.-583, N 24.-P. 3966-3973.

11. Bradford $M$. A rapid and sensitive method for the quantitation of microgram quantities of protein utilizing the principle of protein-dye binding // Anal. Biochem.-1976.-72.P. 248-254.

12. Al-Maghrebi M., Anim J. T., Olalu A. A. Up-regulation of eukaryotic elongation factor-1 subunits in breast carcinoma // Anticancer Res.-2005.-25.-P. 2573-2578.

13. Chi K., Jones D., Frazier M. Expression of an elongation factor 1 gamma-related sequence in adenocarcinomas of the colon // Gastroenterology.-1992.-103, N 1.-P. 98-102.

14. Mimori K., Mori M., Tanaka S., Akiyoshi T., Sugimachi K. The overexpression of elongation factor 1 gamma mRNA in gastric carcinoma // Cancer.-1995.-75, N 6 (Suppl.).P. 1446-1449.

15. Lew Y., Jones D., Mars W., Evans D., Byrd D., Frazier M. Expression of elongation factor-1 gamma-related sequence in human pancreatic cancer // Pancreas.-1992.-7, N 2.-P. 144152.

16. Olarewaju O., Ortiz P. A., Chowdhury W. Q., Chatterjee I., Kinzy T. G. The translation elongation factor eEF1B plays a role in the oxidative stress response pathway // RNA Biol.-2004.-1, N 2.-P. 89-94.
UDC 577.217:577.112.7 Received 05.05.10 